\title{
SPECIES HYBRIDS AND SPONTANEOUS AMPHIPLOIDS IN THE GILIA LACINIATA GROUP
}

\author{
VERNE GRANT \\ Rancho Santa Ana Botanic Garden, Claremont, California
}

Received 25.ii. $6_{5}$

\section{INTRODUCTION}

ThE Gilia laciniata group is a complex of six interrelated species belonging to the larger assemblage of Leafy-stemmed Gilias (Polemoniacex). The plants are annual herbs with small flowers which grow in sandy places in western North America and temperate South America (plate). They are either diploid $(2 n=18)$ or tetraploid $(2 n=36)$. Reproduction is mainly by autogamy.

The North American species are:

(1) Gilia millefoliata $(2 x)$, which occurs on sand dunes along the coast of northern California and Orgeon;

(2) G. clivorum $(4 x)$-on the central California coast and in the Coast Ranges;

(3) G. nevinii $(4 x)$-on three islands off the coast of southern California and northern Mexico.

The South American species are:

(4) G. lomensis $\left(4^{x}\right)$-on the lomas or dry fog-swept hills of coastal Peru;

(5) G. valdiviensis $(2 x)$ - on the Chilean coast;

(6) G. laciniata (chromosomes unknown), which ranges from the Peruvian Andes to Patagonia.

The taxonomy of the Gilia laciniata group has been dealt with elsewhere (Grant, I966) and the present paper describes the fertility relationships of the species.

\section{MATERIALS AND METHODS}

Five of the six species of the Gilia laciniata group were intercrossed. Living material of $G$. laciniata proper was not available; it is the oldest known species taxonomically, having been described in 1799 , but the least known genetically. Further insight into the nature of the Gilia laciniata group was obtained by outcrossing four of the species to a member of a different species group, G. achilleafolia (in the Gilia capitata group).

The strains used were grown from seeds collected in natural populations. The localities and chromosome numbers of the parental strains are as follows: (I) $G$. millefoliata, $2 n=18$, Pt. Reyes, California; (2) G. clivorum, $2 n=36$, Berkeley hills, California; (3) G. nevinii, $2 n=36$, Santa Catalina Island, California; (4) $G$. lomensis, $2 n=36$, Lima, Peru; (5) G. valdiviensis, $2 n=18$, Limache, Chile; (6) G. achillexfolia, $2 n=18$, San Luis Obispo, California.

$2 \mathrm{~L}_{2}$ 
The crosses were made in an insect-proof screenhouse. The hybrids and their progeny were grown partly in the screenhouse and partly in the experimental field. Pollen fertility of the plants was estimated from the proportion of well-rounded and well-stained grains in aniline blue-lactophenol mounts. Chromosome behaviour was studied in propiono-carmine squashes of dividing PMC's under the brightfield or phase microscope or, often, both.

\section{OBSERVATIONS}

(a) Crossability

The crossing data are summarised in table I. The table shows that a strong incompatibility barrier separates Gilia millefoliata from $G$. clivorum and some strains of $G$. achilleafolia; and $G$. clivorum from $G$. achilleafolia and $G$. lomensis. By contrast, $G$. millefoliata and $G$. lomensis, separated to-day by a distance of 4800 miles, and differing in ploidy, can be crossed in either direction with the greatest of ease. A high degree of crossability also exists between $G$. millefoliata on the one hand and the geographically remote $G$. nevinii and $G$. valdiviensis on the other.

\section{(b) Hybrid morphology}

It was possible to produce $F_{1}$ hybrids from eleven combinations of the parental species. Three hybrid combinations were diploid; seven others from diploid-tetraploid crosses were triploid; and one hybrid was tetraploid. All of the $F_{1}$ hybrids were vigorous.

In morphology the hybrids were intermediate between the parental species in quantitative characters. The triploid hybrids tended to approach the tetraploid parent, as would be expected. For example, the width of the leaf segments was as follows in two diploid-tetraploid hybrid combinations. (I) G. nevinii ( $4 x), 0 \cdot 4-0.6 \mathrm{~mm}$; $\mathrm{F}_{1}, 0.5-\mathrm{I} \cdot 0 \mathrm{~mm}$.; G. millefoliata (2x), I. $3-2 \cdot 3 \mathrm{~mm}$. (2) G. lomensis $(4 x), 3.5 \mathrm{~mm}$.; $\mathrm{F}_{1}$, $2.5 \mathrm{~mm}$.; $G$. valdiviensis $(2 x), 0.5 \mathrm{~mm}$. It will be noted that the $\mathrm{F}_{1}$ approaches the tetraploid parent whether that parent has narrow leaves $\left(G\right.$. nevinii) or broad ones $\left(G\right.$. lomensis). The hybrid $F_{1}$ lomensis $\times$ valdiviensis had a spreading habit of growth like $G$. lomensis.

In several instances involving qualitative characters, however, a triploid hybrid was found to exhibit the characteristics of its diploid parent. Thus in $\mathrm{F}_{1}$ millefoliata $(2 x) \times$ nevinii $(4 x)$, the hairs on the lower stem were glandular as in $G$. millefoliata and not villous as in $G$. nevinii, and the corolla tube was pale yellow like that of $G$. millefoliata rather than purple as in $G$. nevinii.

\section{(c) Hybrid sterility}

The $F_{1}$ hybrids were highly or completely sterile, the majority producing less than I per cent. well-formed pollen grains and few or no seeds (table 2). The $\mathrm{F}_{1}$ of $G$. millefoliata $\times$ nevinii produced Io per cent. good pollen and large quantities of seeds.

The degree of seed sterility can be illustrated by the $\mathrm{F}_{1}$ of $G$. millefoliata $\times$ lomensis. Six hybrid plants flowered freely in an isolation 
TABLE I

Crossability

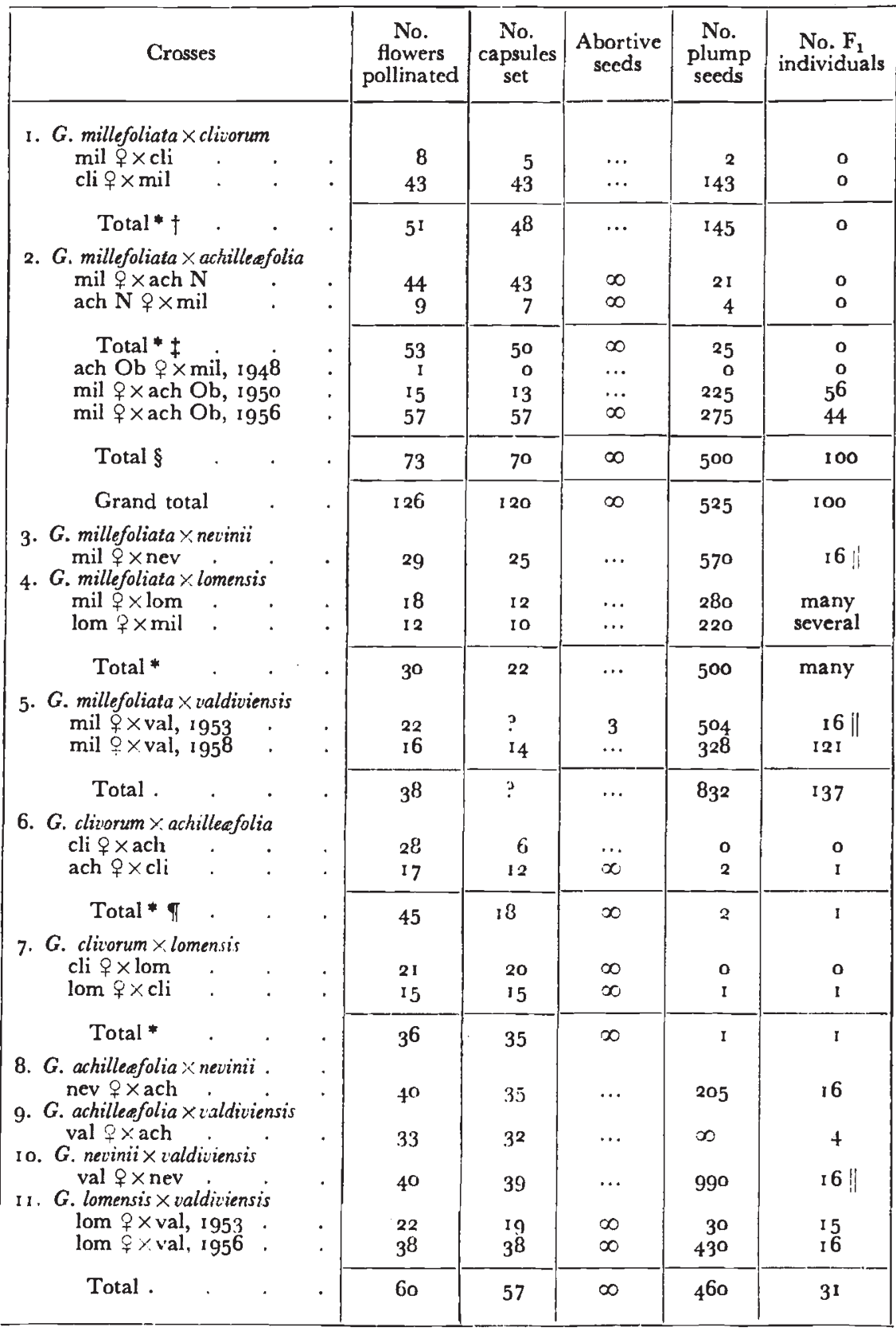

* Summary of data published in Grant, $1954 b$.

$\dagger$ Three strains of $G$. clivorum used.

\# Three northern (N) strains of $G$. achilleefolia used.

$\$$ San Luis Obispo strain (Ob) of $G$. achilleefolia. Data from $194^{8}$ and 1950 crosses (Grant, $1954 b$ ).

II From a fraction of the total number of hybrid seeds.

- Two strains of $G$. clivorum and three of $G$. achailleafoli used. 
plot for II weeks and did not set a single seed. The case is similar in most of the other hybrid combinations.

The seed output listed in table 2 for four hybrids gives a misleadingly high measure of the seed fertility. The $F_{1}$ generations of G. millefoliata $\times$ achilleafolia, G. millefoliata $\times$ valdiviensis, G. millefoliata $\times$ nevinii and $G$. valdiviensis $\times$ nevinii spontaneously produced allopolyploidy progeny in the $F_{2}$ generation. The formation of allopolyploid seeds

TABLE 2

Metaphase pairing and fertility of $F_{1}$ hybrids in Gilia. Pollen fertility is based on $1-7$ plants per cross. The seeds produced are the number from one or several plants. Female parent given first. The dates refer to different cultures

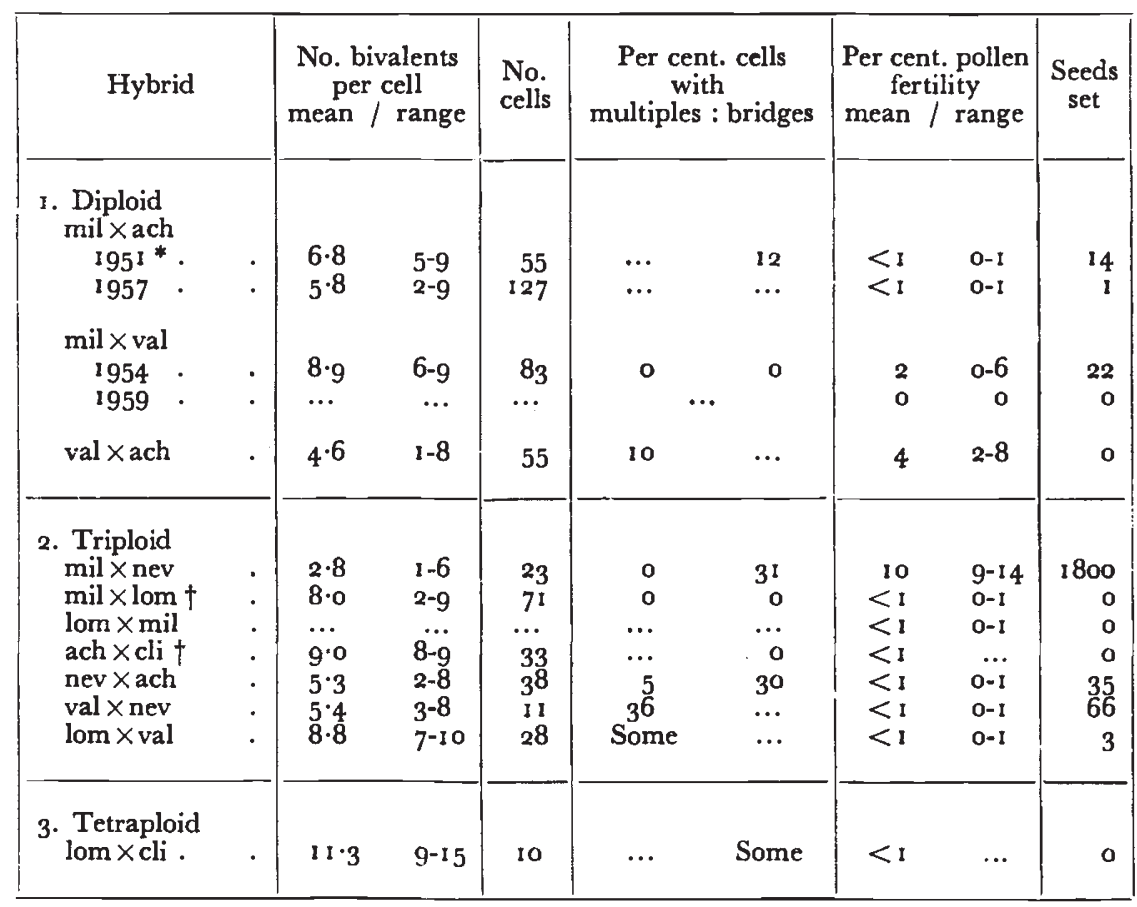

* Meiotic data from Grant (1952).

$\uparrow$ Meiotic data from Grant $(1954 b)$.

by a hybrid is a different matter from seed fertility (Grant, 1952). If allowance is made for the tendency of the four hybrids to produce $F_{2}$ seeds by doubling, they also turn out to be highly seed-sterile on the homoploid level.

\section{(d) Meiotic behaviour of hybrids}

The meiotic behaviour of the $F_{1}$ hybrids is summarised in table 2 and text-fig. 4 and illustrated in text-figs. $1-3$. Most but not all of the hybrids had greatly reduced pairing at metaphase accompanied by lagging at anaphase, as well as other irregularities.

The hybrid of G. millefoliata $\times$ lomensis was triploid and had 9 II +9 I in a majority of the cells and 8.o II as an average figure (Grant, $1954 b$ ). 
An even closer approximation to Drosera type pairing was found in the triploid hybrid of $G$. lomensis $\times$ valdiviensis, which had 9 II +9 I in $20 / 28$ of the cells. The other cells examined deviated from this modal condition in having 7,8 or ro bivalents, and in the occasional presence of a chain-of-three (text-fig. I).

The most unexpected result was the finding of high pairing and regular separation in the sterile hybrid between $G$. millefoliata from California and $G$. valdiviensis from Chile. In a sample of 83 cells at diakinesis or metaphase there were: 75 cells with 9 II (complete pairing), 7 cells with 8 II and I cell with 6 II (see text-fig. 2). A number of clear cells at first anaphase had $9: 9$ distributions to the poles with no lagging. There was no lagging at second anaphase and no micronuclei in the sporads.

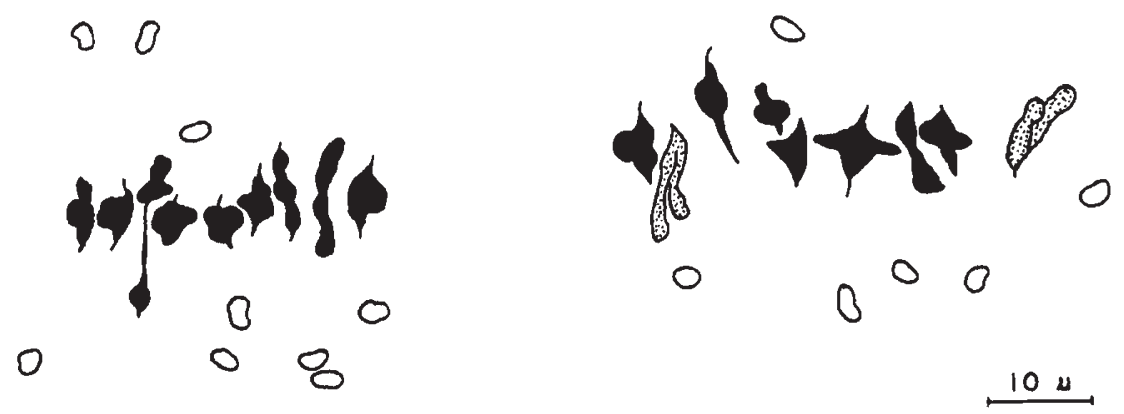

TEXT-FIG. 1.-Chromosome pairing in the triploid hybrid of Gilia lomensis $(4 x) \times$ valdiviensis

(2x). Bivalents shown black, univalents white and trivalents stippled (text-figs. $2-4$ ). In

the right-hand cell one chromosome is missing; it may have been behind a bivalent.

This was the first case encountered in the annual Gilias of a highly sterile hybrid with essentially regular meiosis. The result was so unusual that I considered the possibility of experimental error; the cytological preparations might have been made from buds taken from some undetected selfs in the hybrid culture. With this possibility in mind, I repeated the cross and re-examined meiosis in a new culture. The meiotic behaviour of the plants in the two separate hybrid cultures was exactly the same.

The course of meiosis in the hybrid $G$. millefoliata $\times$ achilleefolia has been described previously (Grant, 1952). The hybrid was produced anew from the same parental strains and re-examined cytologically in 1957 with generally similar results (table 2). Chromosome pairing was reduced and variable in this hybrid; attentuated and heteromorphic bivalents as well as sticky chromosomes occurred in a high proportion of the cells (text-fig. 2).

Similar irregularities of meiosis occur in the hybrid $G$. valdiviensis $\times$ achilleefolia (text-fig. 3). This hybrid had low and variable pairing. Attenuated and heteromorphic bivalents were characteristic of most cells while sticky chromosomes were present in quite a few.

The hybrids between three diploid species (G. millefoliata, valdiviensis 
and achilleafolia) and the tetraploid G. nevinii were triploid and had low variable pairing with much lagging. In $F_{1} G$. nevinii $\times$ achilleafolia,

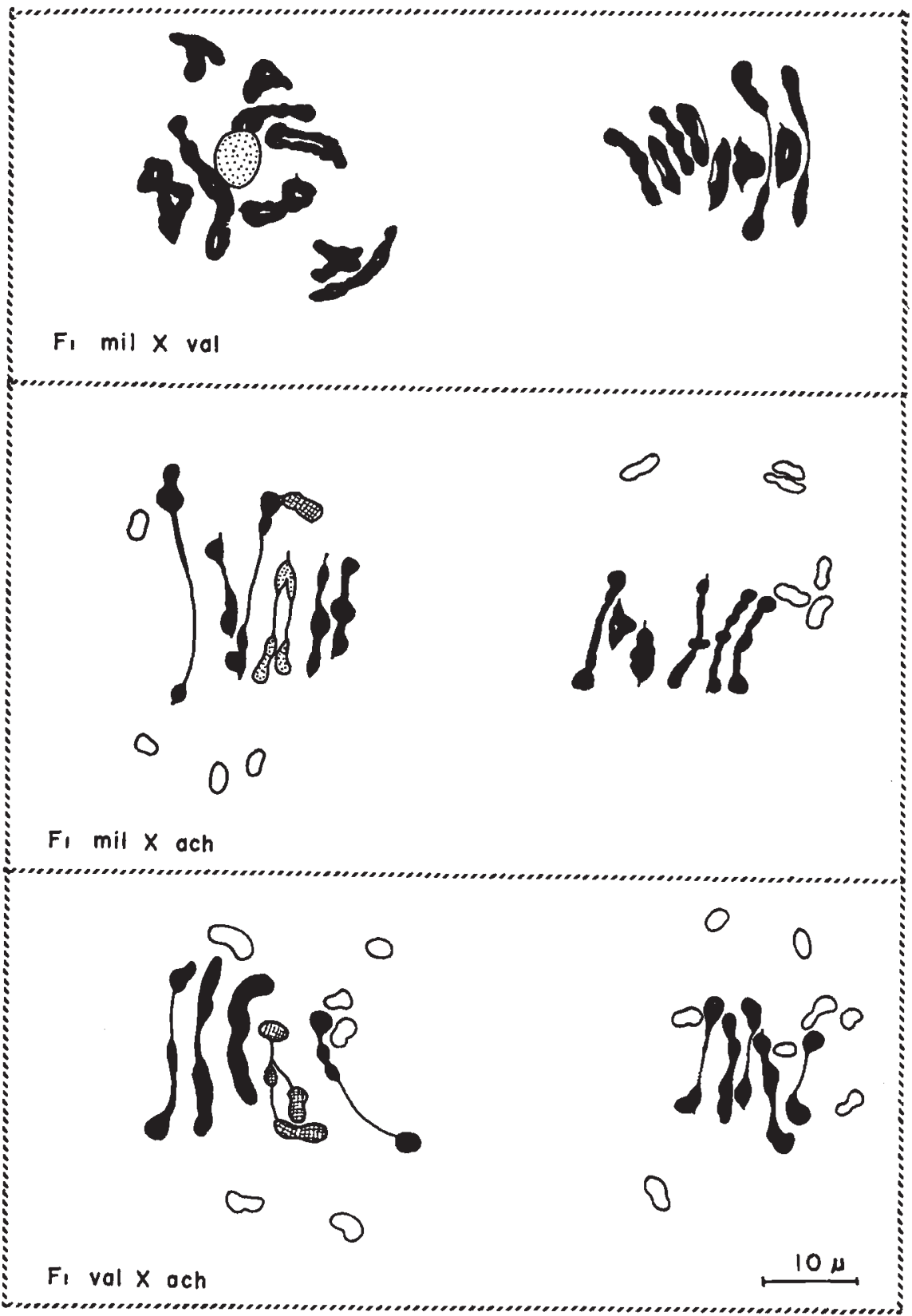

TexT-FrG. 2.-Chromosome pairing in diploid $F_{1}$ hybrids in the Gilia millefoliata-valdiviensisachilleafolia hybrid triangle. Sticky chromosomes cross-hatched.

heteromorphic bivalents, attenuated bivalents and sticky chromosomes were present, as they were in the hybrids between $G$. achilleafolia and 
the diploid relatives of $G$. nevinii, namely $G$. millefoliata and $G$. valdiviensis.

The homøeologous chromosomes in a hybrid, as Darlington pointed out, are differentiated at two levels, genic and segmental and both kinds of differentiation affect the degree of pairing (Darlington, 1932, I 59 ff., 478; and many later workers, i.e. John and Lewis, 1965). Some of the irregularities of pairing in the present group of Gilia hybrids can safely be attributed to structural differences. This is the most likely cause of heteromorphic bivalents, chains and reduced pairing in part at least. Other meiotic phenomena such as sticky chromosomes and attenuated bivalents, which are difficult to account for on structural differences alone, can probably be explained on the basis of disharmonious gene interactions in a species hybrid. It is interesting in this connection to find the parallel occurrence of sticky chromosomes and attenuated bivalents in hybrids between $G$. achilleafolia on the one hand, and the genetically related $G$. millefoliata, valdiviensis and nevinii on the other.

\section{(e) Spontaneous amphiploids}

Four of the hybrid combinations spontaneously produced amphiploid progeny in $\mathrm{F}_{2}$ by the union of unreduced gametes. The amphiploids in question are: $G$. millefoliata-achilleafolia $(4 x=36), G$. millefoliata-valdiviensis $\left(4^{x}=3^{6}\right)$, G. millefoliata-nevinii $(6 x=54-60)$ and $G$. valdiviensis-nevinii $(6 x=54)$. They were generally seed fertile.

The formation, cytology and breeding behaviour of $G$. millefoliataachilleafoliata $\left(4^{x}\right)$ have been described in some detail elsewhere (Grant, I952, I954a). The $\mathrm{F}_{1}$ hybrids produced some restitution nuclei in the second meiotic division and some dyads of microspores. The degree of pairing in the $F_{1}$ hybrids, the frequency of amphiploid progeny in $F_{2}$ and, presumably, the rate of non-reduction at meiosis in $F_{1}$ varied with the nutritional condition of the hybrids. The hybrid cultures yielded in the aggregate 2 I tetrapl. id $F_{n}$ nlants. Most of these had good bivalent pairing $(16-18 \mathrm{II}+4-\ldots$ ) in thost cells (text-fig. 3 ). The $\mathrm{F}_{\mathbf{2}}$ individuals were predominantly semifertile to fully fertile in pollen and seeds. In $F_{3}$ and $F_{4}$ a higher proportion of the plants were meiotically regular and fertile.

The $\mathrm{F}_{1}$ hybrid of $G$. millefoliata $\times$ valdiviensis produced mainly small abortive pollen grains, a small proportion (ca. 2 per cent.) of well-formed grains of "normal" size and a few giant pollen grains in the frequency of about I per 2000 grains. The latter were the same size as the $2 x$ pollen produced by the $F_{2}$ plants and, on this basis, are presumed to be unreduced.

The $\mathrm{F}_{2}$ progeny of $G$. millefoliata $\times$ valdiviensis consisted of ten vigorous tetraploid plants. In the two plants studied cytologically the chromosomes tended to be clumped at metaphase, making an accurate analysis of pairing difficult. Most of the chromosomes were paired in bivalents. Most cells had in addition one or two multivalents, 


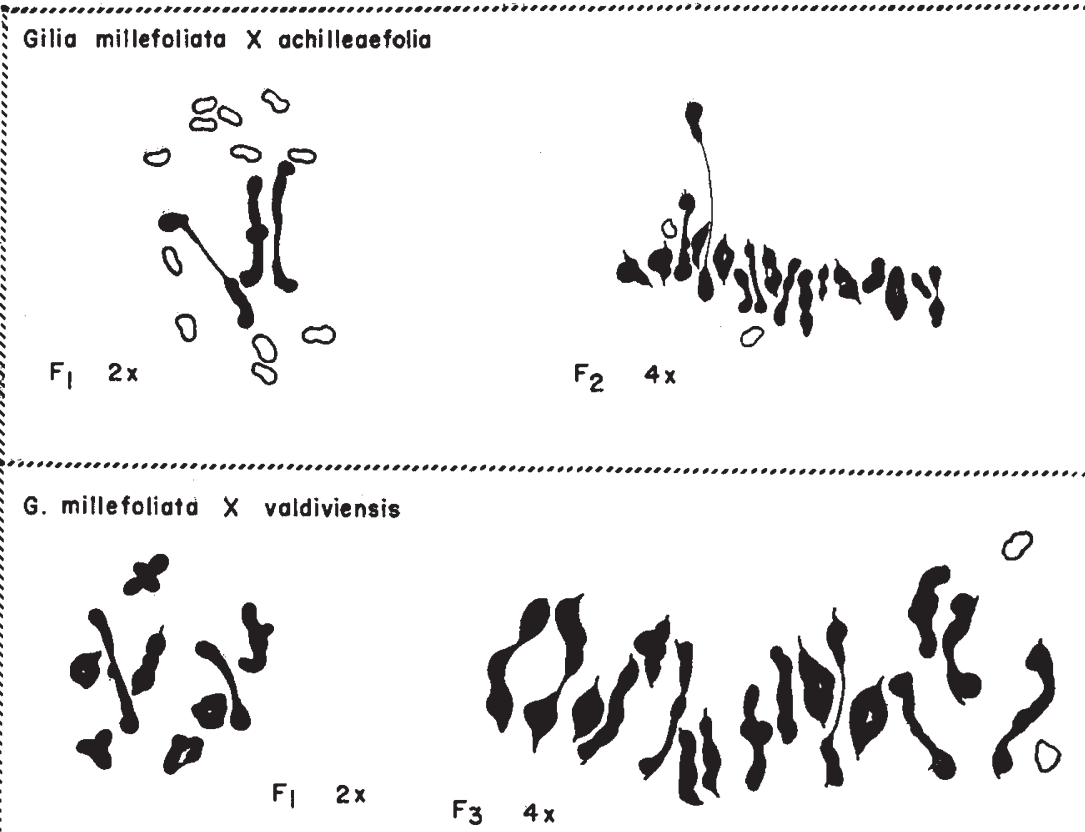

G. millefoliata $X$ nevinii

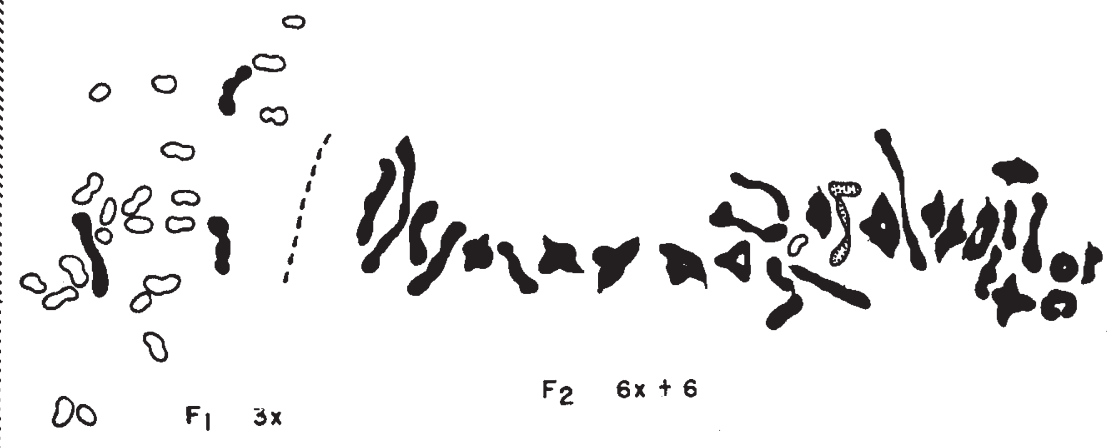

G. valdiviensis $X$ nevinii

$F_{1} \quad 3 x$

104 V.iz $F_{2} 6 x$

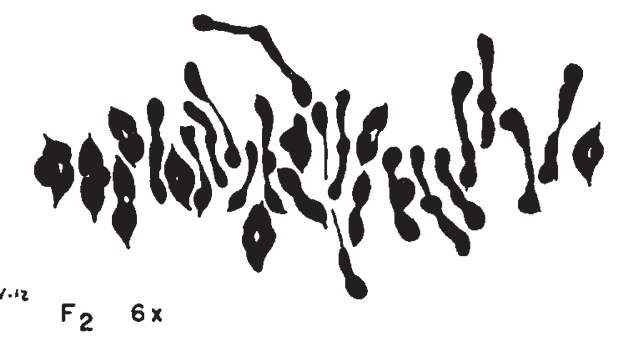

TEXT-FIG. 3-- Chromosome pairing in $F_{1}$ hybrids and their spontaneous amphiploid progeny in four hybrid combinations belonging to the Gilia laciniata group. 
usually trivalents but occasionally a quadrivalent. For example, in one typical cell the configuration was: I 3 II + I IV + I III +3 I. Many cells at first or second anaphase showed clean separations with no lagging. The plants were semifertile as to pollen (23 and 44 per cent. good pollen).

In the following $\left(\mathrm{F}_{3}\right)$ generation the one plant examined had good bivalent pairing with occasional univalents (text-fig. 3 ). Three $\mathrm{F}_{3}$ individuals had $3^{8}, 43$ and $5^{\circ}$ per cent. good pollen.

It will be recalled that the diploid $\mathrm{F}_{1}$ hybrid of $G$. millefoliata $\times$ valdiviensis had almost complete bivalent formation. The occurrence of high bivalent pairing and fertility in the amphiploid derivative of this hybrid suggests strongly that the parental species do differ structurally but that these structural rearrangements are small.

The triploid $\mathrm{F}_{1}$ hybrid of $G$. millefoliata $\times$ nevinii produced some restitution nuclei and a high frequency of dyads of microspores. The hybrid plants set $1800 \mathrm{~F}_{2}$ seeds in the aggregate, of which 300 were sown to yield 202 vigorous $F_{2}$ plants. Two of these plants were examined and found to be at or just above the hexaploid level with 54 and 6o chromosomes respectively. There was good bivalent formation at meiosis. Chains of three and univalents also occurred occasionally (text-fig. 3). The plants were semifertile as to pollen (49 per cent.)

The triploid hybrid of $G$. valdiviensis $\times$ nevinii gave rise to $3^{6}$ vigorous plants in $F_{2}$. One of these was counted and found to be hexaploid $(2 n=54)$. For the most part it had regular bivalent formation (26-27 II +2-o I) and clean anaphase separations (text-fig. 3). Its pollen fertility was high ( 78 per cent.).

\section{(f) Ancestry of the tetraploid species}

The three known tetraploid species of Leafy-stemmed Gilia are $G$. clivorum, $G$. nevinii and $G$. lomensis. The taxogenetic evidence presented here and in earlier papers (Grant, I 954a, I954b) has some bearing on the ancestry of these species.

Gilia clivorum has been shown to be an amphiploid derivative of G. millefoliata $\times$ achillecefolia (Grant, I954a). The meiotic behaviour of the triploid hybrid $G$. achillecfolia $\times$ clivorum and the characteristics of the spontaneous artificial amphiploid $G$. millefoliata-achillecfolia are especially cogent evidences in favour of this derivation of $G$. clivorum.

Gilia lomensis contains a genome of $G$. valdiviensis, as indicated by the pairing relationships in their triploid hybrid, together with another genome as yet unidentified (see text-fig. 4).

The available evidence permits only negative statements regarding the ancestry of $G$. nevinii. This evidence consists of a low frequency of bivalents in the triploid hybrids between $G$. nevinii and $G$. millefoliata, valdiviensis and achillecefolia. We can conclude from this type of pairing that $G$. nevinii is not an autoploid, and does not have $G$. millefoliata, $G$. valdiviensis or $G$. achilleafolia in it. But the identity of its diploid 
ancestors remains unknown (text-fig. 4). There is a distinct possibility on morphological grounds that $G$. angelensis, another species of Leafystemmed Gilia, may enter into the constitution of $G$. nevinii, but the appropriate hybrid has not been produced. It is also possible that one or both diploid ancestors of this island endemic are now extinct.
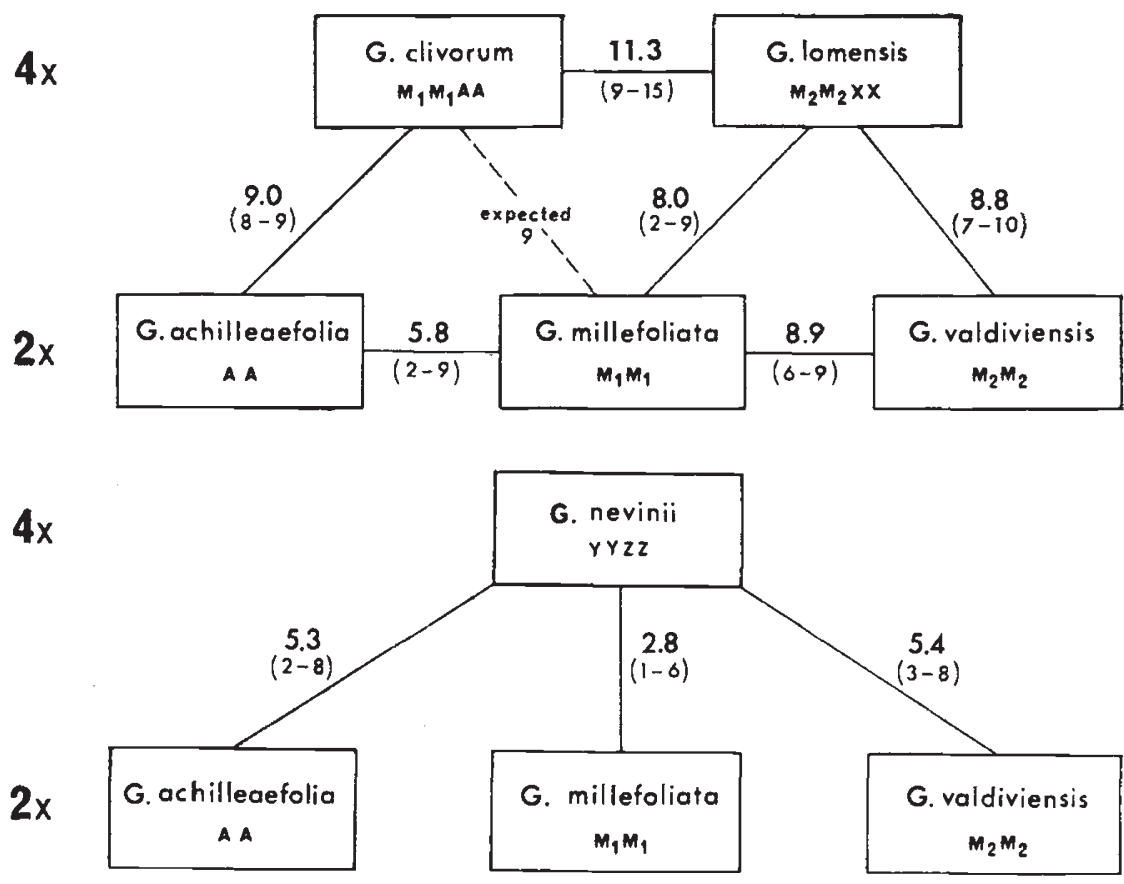

TeXT-FiG. 4.-Number of bivalents per cell (mean and range) in species hybrids in the Gilin laciniala group. The inferred genomic constitution of the species is indicated in the boxes. The letters $\mathrm{X}, \mathrm{Y}, \mathrm{Z}$ are used for unidentified genomes.

\section{DISCUSSION}

Eight species of Leafy-stemmed Gilia have been combined in I5 classes of interspecific hybrids which have reached the stage of flowering (pooled data of this paper and Grant, $1954 b$ ). Four of the I5 classes of interspecific hybrids have doubled spontaneously by the union of unreduced gametes, producing fertile or semifertile amphiploid $F_{2}$ progeny. It is a remarkable fact that all of the hybrids which have thus doubled contain $G$. millefoliata or $G$. valdiviensis in them. One of these hybrids, G. millefoliata $\times$ achilleafolia, doubled repeatedly in three replicate cultures. By contrast, some other hybrid combinations not containing $G$. millefoliata or $G$. valdiviensis have also been produced several times and have consistently failed to produce amphiploids.

There is thus an unusual concentration of one genome-that common to $G$. millefoliata and $G$. valdiviensis-in the sample of artificial amphiploids in the Leafy-stemmed Gilias. What is more, two of the 
three known natural tetraploid species in this section of the genus also carry this genome.

A survey of the results of interspecific crosses in another section of the genus, the Cobwebby Gilias, on the basis of the data given by Grant and Grant (1960), Grant (1964) and Day (1965), reveals a similar highly non-random distribution of genomes among the artificial amphiploids. Interspecific hybrids representing 53 combinations of parental species were grown to flowering. Three of these classes of $F_{1}$ hybrids doubled spontaneously by the union of unreduced gametes. These were $\mathrm{F}_{1} G$. clokeyi $\times$ aliquanta, clokeyi $\times$ mexicana and minor $\times$ clokeyi (Grant and Grant, I96o; Day, I965). It will be noted that all three have $G$. clokeyi as one parent. Parenthetically, Day (1965) was able to obtain a fourth artificial amphiploid in this group, from the hybrid $G$. aliquanta $\times$ minor, by colchicine treatment and somatic doubling, after failure of this hybrid to double spontaneously.

It is interesting to speculate about the factors which probably are or are not responsible for the observed correlation between the presence of certain genomes in a species hybrid and its tendency to produce amphiploid progeny.

Reduced chromosome pairing in a hybrid may set the stage for non-reduction in a general way. But this is a factor common to nearly all interspecific hybrids in the annual Gilias. Indeed, as we have seen, the exceptional hybrid with virtually complete pairing- $G$. millefoliata $\times$ valdiviensis-produced amphiploid second generation hybrids whereas numerous meiotically irregular hybrids did not. Therefore, chromosomal rearrangements which lead to reduced pairing in hybrids can scarcely be a primary factor in the present case.

Environmental conditions have been shown to be correlated with the course of meiosis and the rate of doubling in G. millefoliata $\times$ achilleafolia (Grant, 1952). This hybrid did produce amphiploids under different nutritional conditions, however, though at different rates, whereas other hybrids given a similar range of opportunities did not double at all.

In annual plants an autogamous breeding system is a favourable precondition for the production of amphiploid progeny by a sterile hybrid. Autogamy favours this result by increasing the chances of union of the rare unreduced gametes produced by the hybrids in the hybridising population (Grant, 1956). With rare exceptions, the polyploid species of annual Gilia are, in fact, autogamous themselves and are derived from diploid species which are also autogamous. The spontaneous artificial amphiploids in both the Leafy-stemmed and the Cobwebby Gilias all originated from autogamous $F_{1}$ hybrids. However, many other autogamous interspecific hybrids in these groups did not give rise to amphiploids in the experimental garden. Autogamy, therefore, although presenting a favourable condition for the formation of amphiploids, will not account for the high rate of doubling in certain particular autogamous hybrids. 
It seems likely that the genotype of one or both parental species in a hybrid may affect the critical stage of restitution, and thereby the rate of formation of unreduced gametes and of polyploid progeny. Genotypic factors control many other aspects of the meiotic process, as numerous studies have shown (see Rees, r $96 \mathrm{r}$; Lewis and John, r963), and probably control the rate of doubling too. There is some evidence to support this suggestion.

In Drosophila hydei an autosomal recessive $(l p l)$ is known, which, in homozygous. condition, inhibits the formation and functioning of the spindle and induces restitution and high polyploidy in cells of larval brain tissue (Staiger and Gloor, 1952; Gloor and Staiger, 'r954). The $l p l$ gene acts like colchicine. It is found in a Morocco strain of D. hydei but not in a Zürich strain. A mutant in Antirrhinum majus (mut. cancroidea) has a similar effect in causing endomitosis and the formation of polyploid cells (Stein, r942).

In Datura stramonium a recessive mutation known as dyad, on chromosome 9-10, was induced by radium treatment. This mutant gene has the effect of blocking the second meiotic division in both pollen and embryo-sac mother cells, so that reduced dyads are formed instead of normal tetrads of spores. A diploid plant of dyad constitution when selfed gave rise to some tetraploid progeny (Satina and Blakeslee, 1935; Avery, Satina and Rietsema, 1959, pp. 120, I 76$)$.

Similar cases have been reported in plant species hybrids. The hybrid of Rosa arvensis $\times$ chilensis undergoes endomitosis in some sectors, a process which is suspected to be genically induced (Wulff, r954). Some diploid hybrids of Rumex thyrsiflorus $\times$ acetosa had a tendency, probably gene-controlled since it was inherited in later generations, to produce dyads of unreduced spores. These hybrids gave rise to progeny with approximately the tetraploid chromosome number (Swietlińska, 1960).

It is consistent with such other evidence and with the results reported in this paper to suggest that Gilia millefoliata, G. valdiviensis and $G$. clokeyi carry genes which act in hybrids to promote non-reduction at a relatively high rate. More data are needed, however, to test this suggestion and to define the postulated genic effects in specific terms.

\section{SUMMARY}

I. The Gilia laciniata group consists of six species of autogamous annual plants belonging to the larger assemblage of Leafy-stemmed Gilias (Polemoniaceæ). Three species occur in Pacific North America (G. millefoliata $(2 x)$, G. clivorum $(4 x)$, G. nevinii $(4 x)$ ), and three in temperate South America ( $G$. valdiviensis $(2 x)$, G. lomensis $(4 x)$, G. laciniata (unknown genetically)).

2. The present study is concerned with the fertility relationships of five of these species with one another, and with a sixth species of 

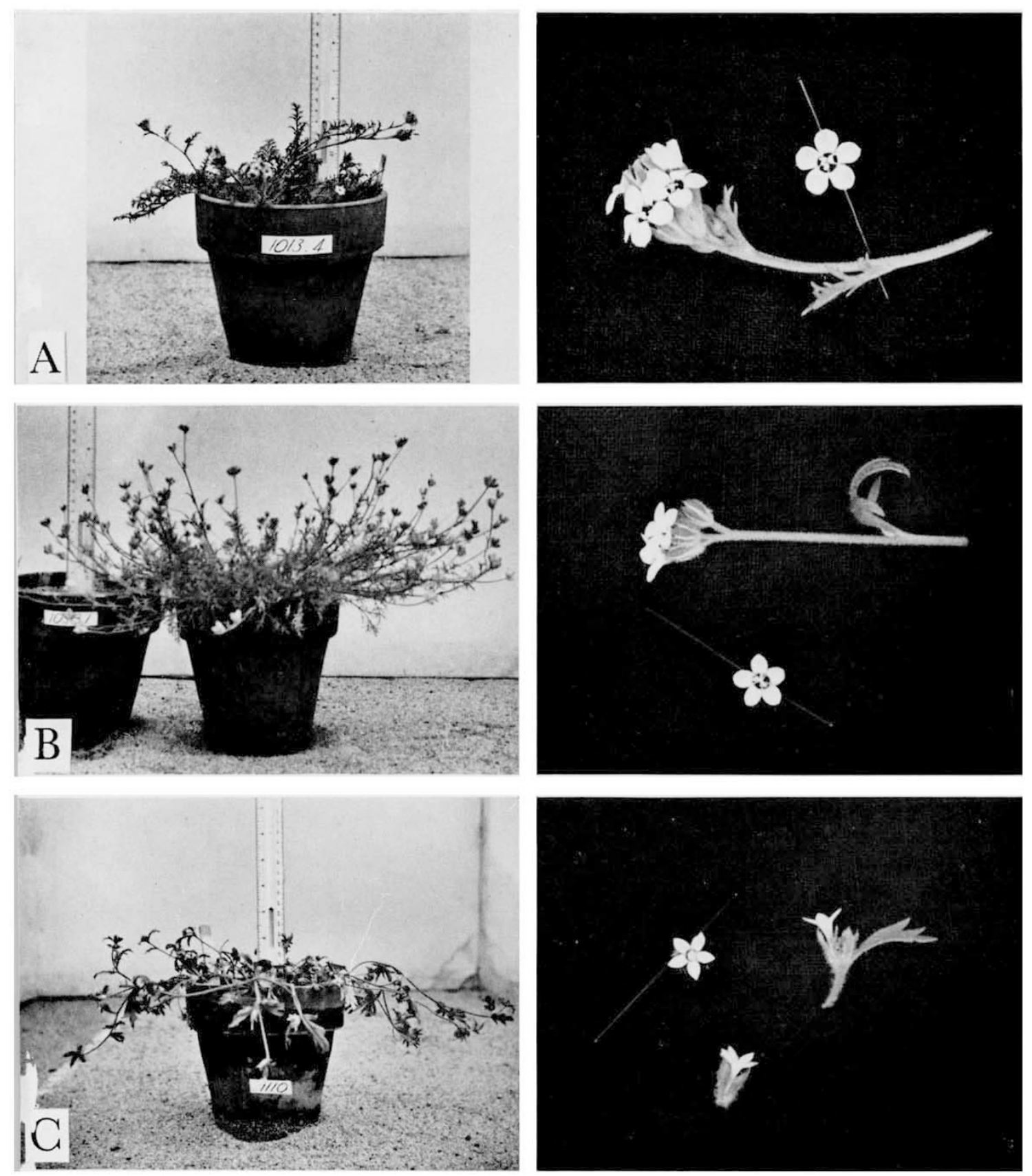

Three parental types in the Gilia laciniata group. (A) G. millefoliata, 2x, Pt. Reycs, California.

(B) G. clivorum, 4x, Berkeley, California. (C) G. lomensis. $4 x$, I.jma. Peru. 
Leafy-stemmed Gilia ( $G$. achilleafolia $(2 x)$ ) which belongs to a different group.

3. The species of the Gilia laciniata group can be crossed inter se with the greatest of ease. High crossability is found between parental species separated by wide geographical gaps, as between California and Peru or Ghile, or by differences in ploidy, as in $4^{x}+\times 2 x$ or $2 x+\times 4 x$ crosses.

4. The species hybrids are highly sterile. They usually exhibit reduced chromosome pairing and/or other meiotic irregularities. The $F_{1}$ hybrid of $G$. millefoliata $(2 x) \times$ valdiviensis $(2 x)$ is exceptional in the annual Gilias as a whole in having nearly complete pairing.

5. The millefoliata genome is in the California tetraploid species, G. clivorum, and the very similar valdiviensis genome is in the Peruvian tetraploid species, $G$. lomensis.

6. Four interspecific hybrids spontaneously produced amphiploid $\mathrm{F}_{2}$ progeny by the union of unreduced gametes. The raw amphiploids had good bivalent pairing and were semifertile or fully fertile. All four classes of amphiploids had the millefoliata or valdiviensis genome in them.

7. A survey of the distribution of spontaneous artificial amphiploids among numerous hybrid combinations in the annual Gilias reveals a high concentration of certain particular parental species. Some of the factors which may be responsible for the non-random distribution of parental species in artificial amphiploids are discussed. It seems likely that non-reduction in hybrids may be affected, not only by the degree of genomic differentiation between the parental species, but also by the genic contents of the genomes, i.e. some genotypes may promote non-reduction in sterile hybrids at a relatively high rate.

Acknowledgments.- This work has been aided by research grants from the National Science Foundation (U.S.A.). Dr A. Garaventa collected the seeds of Gilia valdiviensis in Chile, and Drs O. Velarde and M. Reiche the seeds of G. lomensis in Peru. Dr Alva Day made the crosses. I discussed the interpretation of certain chromosome configurations with Dr Harlan Lewis. Mrs Karen A. Grant critically read the manuscript. My sincere thanks are extended to these individuals for their help and to the National Science Foundation for its financial support.

\section{REFERENCES}

Avery, A. G., SATiNA, S., AND RIETSEMA, J. 1959. Blakeslee: the Genus Datura. New York.

DARLIngton, C. D. 1932. Recent Advances in Cytology. London and Philadelphia. DAY, A. 1965. The evolution of a pair of sibling allotetraploid species of Cobwebby Gilias (Polemoniaceæ). Aliso, 6, 25-75.

GLOOR, H., AND STAIGER, H. 1954. Lethal-polyploid-a polyploid gene in Drosophila hydei. J. Heredity, 45, 289-293.

GRANT, v. 1952. Cytogenetics of the hybrid Gilia millefoliata $\times$ achilleafolia. I. Variations in meiosis and polyploidy rate as affected by nutritional and genetic conditions. Chromosoma, 5, 372-390.

GRANT, v. 1954a. Genetic and taxonomic studies in Gilia. V. Gilia clivorum. Aliso, 3, 19-34. 
GRANT, V. 1954b. Genetic and taxonomic studies in Gilia. VI. Interspecific relationships in the Leafy-stemmed Gilias. Aliso, 3, 35-59.

GRANT, v. 1956. The influence of breeding habit on the outcome of natural hybridisation in plants. Amer. Nat., 90, 319-322.

CRANT, v. I964. Genetic and taxonomic studies in Gilia. XII. Fertility relationships of the polyploid Cobwebby Gilias. Aliso, 5, 479-507.

GRANT, v. 1966. Genetic and taxonomic studies in Gilia. XIII. The Gilia laciniata group. Aliso, 6 , in press.

GRANT, V., AND GRANT, A. Ig6o. Genetic and taxonomic studies in Gilia. XI. Fertility relationships of the diploid Cobwebby Gilias. Aliso, 4, 345-48I.

JoHN, B., AND LEWIS, K. R. $\quad 1965$. Genetic speciation in the grasshopper Eyprepocnemis plorans. Chromosoma, 16, 308-344.

LEWIS, K. R., AND John, в. 1963. Chromosome Marker. London and Boston.

REES, H. I96I. Genotypic control of chromosome form and behaviour. Bot. Rev., 27, 288-318.

satina, S., AND blakeslee, A. F. 1946. Cytological effects of a gene in Datura which causes dyad formation in sporogenesis. Bot. Gaz., 96, 52 1-523.

STAIGer, H., AND GlOOR, H. 1952. Mitosehemmung und Polyploidie durch einen Letalfaktor (lpl = Letal-Polyploid) bei Drosophila hydei. Chromosoma, 5, 22 I-245. stein, E. 1942. Cytologische Untersuchungen an Antirrhinum majus mut. cancroidea. Endomitosen-Entwicklung. Chromosoma, 2, 308-333.

SWIETLiŃskA, z. I96o. Spontaneous polyploidization in Rumex hybrids. Acta Soc. Bot. Polon., 29, 79-98.

WUlfF, H. D. 1954. Ueber das spontane Auftreten einer Caninae-Meiosis bei der Mikrosporogenese der diploiden Rosa ruga Lindl. Oesterr. Bot. Zeitschr., ror, 539-557. 